Retna Tri Astuti',Lailatul Nur Hidayati $^{2}$, Listiana ${ }^{3}$,Farihah Abghi Rusda ${ }^{4}$, Rachel Pasa Vicha Abdilla ${ }^{5}$

1Prodi Keperawatan Fakultas IImu Kesehatan

2,3,4,5Mahasiswa Fakultas IImu Kesehatan Universitas Muhammadiyah Magelang Jalan Mayjen Bambang Soegeng No.Km 5,

Glagak, Sumberrejo, Kecamatan

Mertoyudan, Magelang, Jawa Tengah 56172

Email: retnatriastuti@ummgl.ac.id

\section{Peningkatan Kapasitas Perempuan dalam Kesehatan Jiwa Keluarga Di masa Pandemi Covid-19}

DOI: 10.18196/berdikari.v9i2.10563

\begin{abstract}
The Covid-19 pandemic that has occurred in the world has spread to Indonesia. Caused by the Covid-19 pandemic only on the health aspect but also on the social and economic aspects the impact not only has an impact on increasing problems. This problem is also experienced by the people of Ngapus Village. Ngapus village is a village prone to landslides. Most of the people in Ngapus Village work as farmers. The level of community education is low, namely elementary and junior high school graduates so that the income level of the community in Ngapus Village is still below the average. With the Covid-19 pandemic, it will certainly increase the poverty level in this village to a high level. Women like women in other villages also rose up and played a role in overcoming the socio-economic problems of the family. In helping to meet the needs of the family sometimes experience stress so it is necessary to make mental health efforts, especially at the family level. This program aims to help improve the mental health condition and preparedness of Ngapus Village residents. The method used to achieve this goal is through non-formal education for women, this is easier for the Dasawisma group because they are a vulnerable group. The implementation of community development is carried out through non-formal education, namely training carried out with lectures, discussions, practices and assistance to Mrs. Dasawisma, namely health about covid-19 and trauma healing due to the Covid-19 pandemic, in addition to training on making herbal drinks. The results of the implementation of this community development program are an increase in the knowledge and skills of mothers in the mental health of Dasawisma and an increase in preparedness in the field of mental, social and economic health during the Covid-19 pandemic.
\end{abstract}

Keywords: women's empowerment, mental health, covid-19

\footnotetext{
ABSTRAK

Pandemi Covid-19 yang terjadi di dunia menyebar ke Indonesia. Dampak Pandemi Covid-19 dialami oleh masyarakat berbagai aspek, yakni ekonomi, sosial, dan bahkan budaya, tidak terkecuali warga Desa Ngapus, Salaman, Muntilan. Masyarakat Desa Ngapus sebagian besar berprofesi sebagai petani. Tingkat pendidikan masyarakat tergolong rendah yaitu tamatan SD dan SMP sehingga tingkat pendapatan masyarakat di Desa Ngapus masih di bawah rata-rata. Dengan adanya pandemi Covid-19 tentunya akan meningkatkan tingkat kemiskinan di desa ini hingga level yang tinggi. Perempuan seperti perempuan di desa lain juga bangkit dan berperan dalam mengatasi masalah sosial ekonomi keluarganya. Dalam membantu mencukupi kebutuhan keluarga adakalanya mengalami stress sehingga perlu dilakukan upaya penyehatan jiwa terutama pada level keluarga. Program ini bertujuan untuk membantu meningkatkan kondisi Kesehatan mental dan kesiapsiagaan warga Desa Ngapus. Metode yang dipakai untuk mencapai tujuan itu adalah
} 
dengan melalui pendidikan nonformal bagi perempuan, hal ini lebih mudah dilakukan pada kelompok Dasawisma karena mereka merupakan kelompok rentan. Pelaksanaan bina lingkungan dilakukan melalui pendidikan nonformal yaitu pelatihan yang dilakukan dengan ceramah, diskusi, praktek dan pendampingan kepada ibu Dasawisma yaitu pelatihan kesehatan tentang covid-19 dan trauma healing akibat pandemi Covid-19, disamping itu juga pelatihan pembuatan minuman herbal. Hasil dari pelaksanaan program bina lingkungan ini adalah peningkatan pengetahuan dan keterampilan ibu-ibu dalam kesehatan jiwa Dasawisma serta peningkatan kesiapsiagaan di bidang kesehatan jiwa, sosial dan ekonomi pada saat pandemi Covid19.

Kata kunci: pemberdayaan wanita, kesehatan mental, covid-29

\section{PENDAhuluan}

Kejadian bencana terbesar saat ini yang dialami oleh seluruh dunia adalah adanya Kejadian Luar Biasa (KLB) berupa pandemi covid-19 yang terjadi pertama kali di Wuhan, Cina dan menyebar ke seluruh dunia termasuk Indonesia. Hasil data dari WHO pada tanggal 11 November 2020 total kasus terkonfirmasi adalah 448.118 (3.770 kasus baru), 14.836 kasus meninggal, dan total kasus sembuh 378.982 (Organization, 2020). Sedang data dari Kemenkes per 30 November 2020 situasi globa total kasus konfirmasi Covid19 adalah 62.363.527 kasus dengan 1.456.687 kematian (CFR 2,3\%) di 219 negara terjangkit dan 180 negara transmisi lokal. Sedangkan data di Indonesia 538.883 kasus konfirmasi, 16.945 kasus meninggal (3,1\%), dan 450.518 kasus sembuh (PHEOC, 2020).

Peningkatan kasus di berbagai pelosok daerah di Indonesia membuat pemerintah terus melakukan upaya pencegahan dan penanggulangan penyebaran covid-19 dengan menerapkan protokol kesehatan yaitu 3M wajib bagi masyarakat dan upaya baru yang dikeluarkan yaitu dengan melakukan Test, Trace dan Treat (3T) dan melakukan isolasi mandiri (RI, 2021; Suni, 2020). Selain itu, upaya Pembatasan Sosial Berskala Besar (PSBB) juga telah diberlakukan diberbagai daerah di Indonesia (Listyorini, 2020; Z., 2020).

Dampak yang diakibatkan dari kebijakan yang pemerintah lakukan tidak hanya pada aspek kesehatan saja, tetapi juga berdampak pada aspek sosial ekonomi warga masyarakat di Indonesia. Dampak sosial yang dirasakan adalah adanya keterbatasan pada interaksi langsung dengan keluarga, saudara, teman, dan akses pelayanan kesehatan. Selain itu, pandemi covid-19 akan menyebabkan resesi global pada sektor ekonomi dan jutaan orang akan mengalami kemiskinan. Hasil penelitian menyatakan bahwa proyeksi awal dari dampak pandemi covid-19 ini, pertumbuhan ekonomi Indonesia pada tahun 2020 sebesar 5\% akan diperkirakan turun ke kisaran angka 1\%-4\%. Dampak paling ringan pandemi covid-19 pada pertumbuhan ekonomi, yaitu kenaikan kemiskinan dari 9,2\% pada September 2019 ke 9,7\% pada akhir 2020 dengan perkiraan ada 1,3 juta orang 
mengalami kemiskinan (Suryahadi et al., 2020; Sakri, 2020). Kenyataan yang ada di lapangan saat ini menurut catatan Badan Pusat Statistik (BPS) pada tanggal 5 Mei 2020 melaporkan bahwa per Februari 2020 sebelum pandemi covid-19 terjadi, angka pengangguran di Indonesia mencapai 6,88 juta lalu naik menjadi 60.000 orang pertahun dan ini akan terus bertambah seiring dengan masa darurat pandemi covid-19 (DW, 2020). Hal ini mengakibatkan banyaknya keluhan yang disampaikan oleh masyarakat terutama kepala keluarga (suami) yang mengalami kesulitan dalam mencari pekerjaan kembali sehingga ini berimbas pada kesulitan pemenuhan kehidupan sehari-hari.

Permasalahan di atas tentu saja berimbas pada perempuan atau istri. Keluarga merasa stres dengan kondisi perekonomian keluarga mereka. Para perempuan mengatakan cemas dengan kondisi keluarganya jika suaminya tidak bekerja. Para ibu dasawisma mengatakan mereka sering kebingungan ketika anak mereka meminta pulsa untuk paket sekolah dan untuk biaya kehidupan sehari-hari. Untuk mengatasi permasalahn tersebut, para istri atau perempuan ikut bangkit untuk dapat menompang permasalahan ekonomi dalam keluarganya. Berbagai upaya yang dilakukan oleh perempuan mulai dengan berdagang, menjadi buruh, dan lain-lainnya. Hal ini tentu saja menjadikan perempuan memiliki peran ganda, yaitu harus bekerja serta mengurus anak dan keluarga. Hal ini juga dialami oleh masyarakat Desa Ngapus, Kecamatan Salaman selama pandemi covid19 ini. Sebelum pandemi covid-19 terjadi, masyarakat Desa Ngapus mayoritas bekerja sebagai petani. Kehidupan para istri atau perempuan di desa Ngapus lebih banyak berperan sebagai ibu rumah tangga. Desa Ngapus ini juga merupakan desa yang rawan terjadinya bencana tanah longsor.. Tingkat pendidikan masyarakat tergolong rendah yaitu lulusan SD dan SMP sehingga tingkat pendapatan masyarakat di Desa Ngapus masih di bawah rata-rata. Dengan adanya pandemi covid-19 ini, tentu akan menambah tingkat kemiskinan di desa ini menjadi tinggi. Hal ini tentu saja diperlukan upaya untuk mengatasi permasalahan kesehatan jiwa dan kesehatan secara umum, sosial, dan ekonomi.

Salah satu upaya yang dilakukan adalah dengan melakukan kegiatan pemberdayaan masyarakat. Adapun kegiatan yang dilakukan adalah melalui pengabdian masyarakat (PPMT) yaitu melakukan pendidikan nonformal bagi ibu-ibu dasawisma melalui program dasawisma SEJIWA yaitu dasawisma yang sehat jiwa, sosial, dan ekonomi. Program yang dilakukan adalah dengan melakukan pelatihan dalam upaya pencegahan dan penanggulangan dampak pandemi covid-19 secara holistik dan pelatihan pembuatan minuman herbal untuk peningkatan sosial ekonomi para perempuan di Desa Ngapus. Tujuan dari program ini adalah membantu meningkatkan kondisi kesehatan mental dan kesiapsiagaan warga Desa Ngapus. 


\section{METODE PELAKSANAAN}

Metode pengabdian ini dilakukan selama 1 bulan melalui tahapan kegiatan, yaitu:
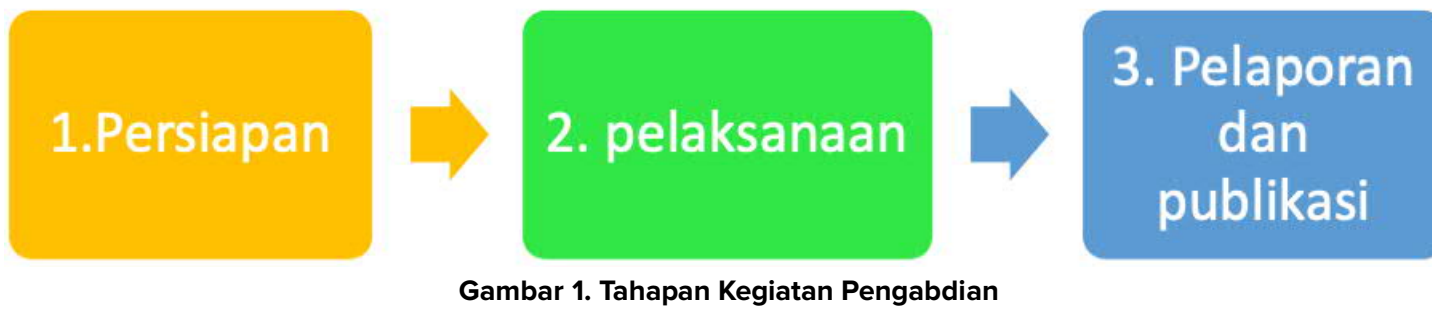

1. Persiapan meliputi FGD dengan desa sasaran terutama mitra untuk menentukan prioritas permasalahan yang akan dilakukan penyelesaian serta pengajuan izin pelaksanaan kegiatan di Dusun Ngapus, Desa Kalisalak, Kecamatan Salaman, Kabupaten Magelang.

2. Pelaksanaan kegiatan meliputi kegiatan sosialisasi, pelatihan dan praktik, pendampingan, serta monitoring dan evaluasi. Adapun metode yang dilakukan meliputi:

a. Sosialisasi, sosialisasi yang dilakukan meliputi sosialisasi terkait program kerja dan kesehatan yaitu perawatan kesehatan jiwa dan penyakit selama pandemi covid-19.

b. Pelatihan, pelatihan yang dilakukan dalam program ini adalah pelatihan yang dilakukan dalam 7 pertemuan. Metode yang dilakukan dengan diskusi dan praktik terkait manajemen kesehatan jiwa terkait terapi SEFT, relaksasi napas dalam untuk mengatasi kecemasan dan traumatik, dan pelatihan kemampuan diri dengan pelatihan jamu herbal yang berbasis sumber daya alam yang dimiliki warga.

c. Pendampingan, pendampingan dilakukan untuk pelaksanaan program Dasa Wisma adalah pendampingan yang di lakukan pelaksanaan kegiatn PPMT untuk mendampingi remaja dalam melaksanakan prongram tersebut.

3. Pelaporan dan publikasi hasil pengabdian yaitu berupa penyusunan laporan kemajuan, laporan akhir, publikasi di media massa dan prosiding/jurnal ilmiah serta adanya video kegiatanHasil dan Pembahasan

Kegiatan pemberdayaan masyarakat telah dilakukan selama 1 bulan yang dilakukan di Ngapus, Kalisalak, Kecamatan Salaman, Kabupaten Magelang. Dasawisma ini diikuti oleh 12 orang. Sepuluh orang merupakan ibu rumah tangga dan 2 orang pegawai swasta. Pendidikan nonformal yang dilakukan pada dasawisma ini adalah:

\section{Pelatihan Trauma Healing Dampak Bencana Pandemi Covid-19.}

Pelatihan kesehatan ini dilakukan dengan tujuan meningkatkan kesiapsiagaan ibu- 


\section{5}

ibu dalam mengatasi dampak psikologi yang terjadi akibat pandemi covid-19. Pada pelatihan ini dilakukan sebanyak 3 kali pertemuan dengan materi tentang covid-19 dan dampak kesehatan yang terjadi, Post Traumatic Stress Disorder (PTSD) dan manajemen trauma healing. Pertemuan dihadiri oleh 12 orang. Hasilnya adalah adanya peningkatan sebelum dilakukan pelatihan yaitu tingkat pengetahuan dan ketrampilan terbanyak rendah sebesar $84 \%$. Sedangkan setelah dilakukan pelatihan ada peningkatan pada tingkat pengetahuan dan ketrampilan sedang sebesar 58\%. Hal ini dapat dilihat pada Tabel 1 di bawah ini.

Tabel 1. Tingkat Pengetahuan dan Ketrampilan Trauma Healing Dampak

\begin{tabular}{ccccc}
\hline $\begin{array}{c}\text { Tingkatan Pengetahuan } \\
\text { dan Ketrampilan }\end{array}$ & \multicolumn{2}{c}{ Sebelum Pelatihan } & \multicolumn{2}{c}{ Sesudah Pelatihan } \\
\hline & Frekuensi & Persentase & Frekuensi & Persentase \\
\hline Tinggi & 1 & $8 \%$ & 5 & $42 \%$ \\
\hline Sedang & 1 & $8 \%$ & 7 & $58 \%$ \\
\hline Rendah & 10 & $84 \%$ & 0 & $0 \%$ \\
\hline & 12 & $100 \%$ & 12 & 100 \\
\hline
\end{tabular}

Penerapan pelatihan ini dapat dilihat pada Gambar 1 di bawah ini.


Gambar 1. Pelatihan Trauma Healing Dampak Bencana Covid-19

\section{Pelatihan Pembuatan Minuman Herbal}

Pelatihan pembuatan minuman herbal ini merupakan pelatihan dalam upaya peningkatan sosial ekonomi masyarakat selama pandemi covid-19. Pelatihan ini dilakukan 3 kali yang dihadiri oleh 12 orang peserta. Pelatihan yang dilakukan mulai dari pembuatan kebun toga, pembuatan serbuk instan (simplisia), dan pemasaran. Hasil yang dicapai dari pelatihan ini adalah peningkatan pengetahuan ibu-ibu dasawisma terkait pembuatan minuman herbal, bahan yang bisa dibuat, penanaman, dan pemasaran minuman herbal tersebut, yaitu sebelum dilakukan pelatihan sebanyak 92\% ibu-ibu masih tingkat 
pengetahuan dan ketrampilannya rendah dan setelah dilakukan pelatihan sebanyak $84 \%$ tingkat pengetahuannya tinggi (Tabel 2).

Tabel 2. Tingkat Pengetahuan dan Ketrampilan Pembuatan Minuman herbal

\begin{tabular}{ccccc}
\hline $\begin{array}{c}\text { Tingkatan Pengetahuan } \\
\text { dan Ketrampilan }\end{array}$ & \multicolumn{2}{c}{ Sebelum Pelatihan } & \multicolumn{2}{c}{ Sesudah Pelatihan } \\
\hline Finggi & 0 & $0 \%$ & Frekuensi & Persentase \\
\hline Sedang & 1 & $8 \%$ & 10 & $84 \%$ \\
\hline Rendah & 11 & $92 \%$ & 2 & $16 \%$ \\
\hline & 12 & $100 \%$ & 0 & 100 \\
\hline
\end{tabular}

Selain itu, ibu-ibu dasawisma juga mampu membuat minuman herbal bentuk serbuk instan maupun bentuk lain dan cara pengemasannya. Pelatihan ini dapat dilihat pada Gambar 2 dibawah ini.
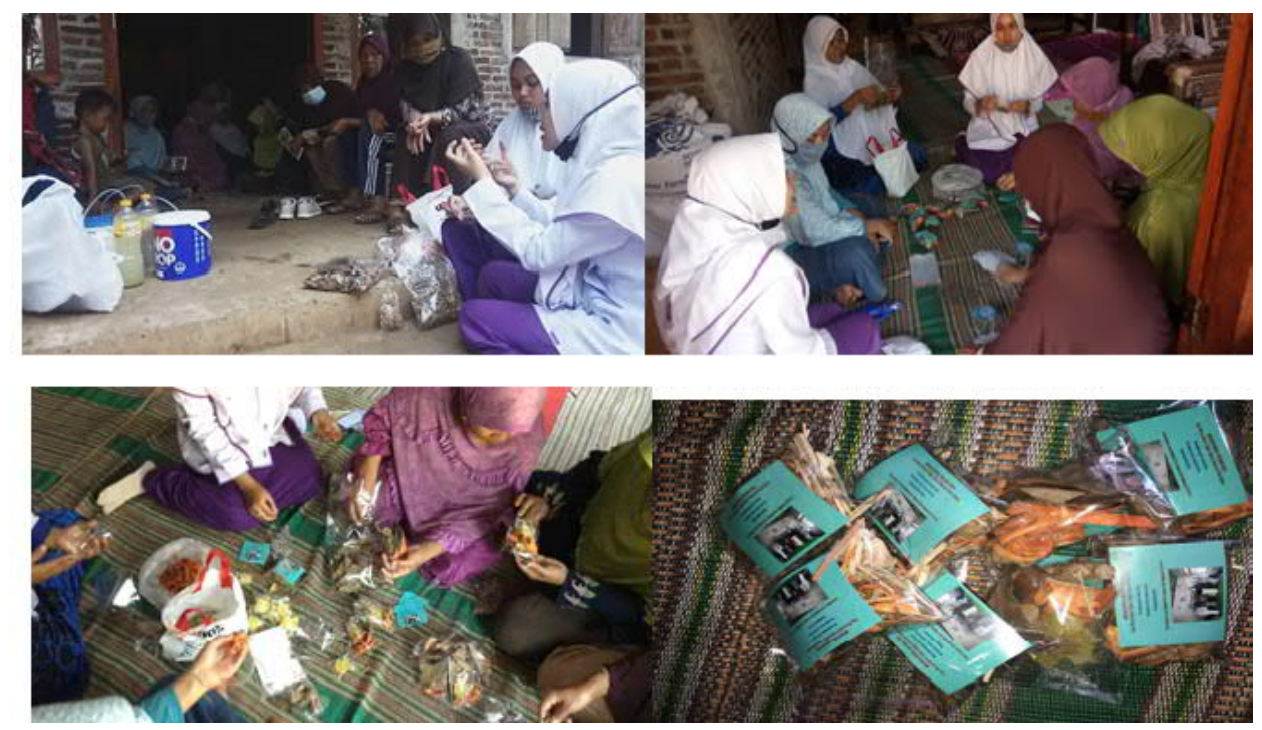

Gambar 2. Pelatihan Pembuatan Minuman Herbal

Pemberdayaan yang telah dilakukan melalui pendidikan nonformal melalui ibu-ibu dasawisma ini merupakan wujud pelaksanaan dalam pembangunan yang melibatkan masyarakat untuk mengubah kehidupan yang lebih baik di masa pandemi covid-19. Pemberdayaan masyarakat ini dilakukan dengan peningkatan kapasitas masyarakat yang berfungsi untuk menangani permasalahan kesehatan dan sosial ekonomi warga masyarakat pada masa pandemi covid-19. Permasalahan yang diakibatkan oleh pandemi ini sangatlah kompleks, tidak hanya sebatas permasalahan kesehatan saja, tetapi 
permasalahan sosial ekonomi masyarakat juga dialami oleh warga. Permasalahan yang terjadi antara lain dengan adanya pembatasan sosial berskala besar menjadikan warga banyak kehilangan pekerjaan dan pendapatan sehingga banyak warga yang mengalami permasalah psikososial dan kejiwaan (Giorgi et al., 2020; Ravaldi \& Vannacci, 2020).

Pemberdayaan masyarakat yang dilakukan ini bertujuan untuk meningkatkan kapasitas masyarakat atau orang-orang yang lemah serta program ini berfungsi untuk basis penanganan permasalahan sosial di dalam masyarakat kontemporer (Ife, 2016). Pemberdayaan masyarakat dapat melibatkan pengorganisasaian orang dan kelompok melalui ibu-ibu dasawisma dalam melakukan tindakan sosial atau politik dalam upaya peningkatan berbagai aspek kehidupan, baik ekonomi maupun nonekonomi melalui pendidikan nonformal yaitu dengan pelatihan di bidang kesehatan dan pelatihan di bidang sosial ekonomi.

Pemberdayaan masyarakat yang dilakukan melalui ibu-ibu dasawisma ini telah sesuai dengan prinsip pemberdayaan yaitu adanya partisipasi, adanya kesetaraan dan keberlanjutan serta berkeadilan social (Lauer, 2002). Ibu-Ibu dasawisma berpartisipasi dalam program ini dan membantu masyarakat Dusun Ngapus dalam penanganan kesehatan dan peningkatan sosial ekonomi melalui pendidikan nonformal yang dilakukan yaitu pelatihan kesehatan jiwa (trauma healing) dan pelatihan pembuatan minuman herbal yang hasilnya menunjukkan tingkat pengetahuan dan ketrampilan ibu sebelum dilakukan pelatihan trauma healing ada $84 \%$ rendah dan setelah dilakukan pelatihan trauma healing meningkat menjadi sedang 58\%.

Di sisi lain, pada pelatihan herbal didapatkan hasil tingkat pengetahuan dan ketrampilan sebelum pelatihan rendah sebanyak $92 \%$ dan setelah pelatihan meningkat menjadi tingkat pengetahuannya tinggi sebanyak 84\%. Hal ini sesuai dengan pendapat dari Notoatmojo (2014) bahwa pengetahuan merupakan hasil dari tahu setelah orang melakukan penginderaan terhadap sesuatu obyek tertentu. Penginderaan terjadi melalui panca indera manusia, yaitu indera penglihatan, pendengaran, penciuman, rasa, dan raba. Sebagian besar pengetahuan manusia diperoleh melalui mata (penglihatan) dan telinga (pendengaran). Pengetahuan juga dapat diperoleh melalui pendidikan, pengalaman diri sendiri maupun pengalaman orang lain, media massa maupun lingkungan (Notoatmojo, 2014).

Pelatihan yang telah dilakukan dalam pemberdayaan masyarakat ini merupakan bagian dari pendidikan nonformal. Pelatihan ini merupakan pendidikan pelengkap bagi masyarakat yang memberikan manfaat bagi masyarakat pada aspek kesehatan dan peningkatan sosial ekonomi masyarakat (Indonesia, 2003; Hidayat dkk., 2017). Pelatihan 
yang dilakukan kepada ibu-ibu dasawisma ini juga sesuai dengan tujuan dari kegiatan dasawisma itu sendiri, yaitu terciptanya sistem kewaspadaan dan kesiapsiagaan dini masyarakat terhadap kemungkinan terjadinya penyakit dan masalah kesehatan yang akan mengancam dan merugikan masyarakat yang bersangkutan (Wafiyah, 2015). Pelatihan ini akan meningkatkan kesiapsiagaan dini masyarakat terhadap pandemi covid-19, manajemen dampak psikologis selama pandemi covid-19 yaitu, trauma, kecemasan, dan gangguan lain serta peningkatan kesiapsiagaan sosial ekonomi karena dampak pandemi covid-19.

Pelatihan ini memberikan pengaruh yang positif bagi ibu-ibu dasawisma. Hal ini dapat dilihat adanya perubahan pada aspek kognitif dan psikomotor sebelum dan sesudah dilakukan pelatihan. Ibu-ibu dasawisma telah memahami permasalahan kesehatan jiwa dan manajemen kesehatan jiwa serta peningkatan kemampuan ibu-ibu dasawisma dalam upaya penanganan sosial ekonomi akibat pandemi covid-19. Hal ini tentu saja menjadikan peluang bagi ibu-ibu dasawisma untuk dapat meningkatkan kesehatan keluarga dari aspek biologis, psikologis, dan sosial ekonomi selama pandemi covid-19 ini sehingga keluarga siap dan tangguh selama pandemi covid-19 ini berlangsung.

\section{SIMPULAN}

Pemberdayaan masyarakat yang dilakukan melalui pendidikan nonformal dapat membantu meningkatkan kapasistas masyarakat dalam mengatasi permasalahan kesehatan dan sosial ekonomi akibat pandemi Covid-19, antara lain peningkatan pengetahuan dan ketrampilan dalam bidang kesehatan jiwa yaitu terkait trauma healing dampak pandemi covid-19 serta ketrampilan dalam pembuatan jamu herbal sebagai upaya peningkatan sosial ekonomi keluarga. Terutama bagi ibu-ibu dasawisma yang menjadi tulang punggung keluarga dalam menghadapi pandemi covid-19.

\section{UCAPAN TERIMA KASIH}

1. LP3M UM Magelang yang sudah menerima proposal dan memberikan dana dalam pengabdian ini;

2. Dasawisma Dusun Ngapus, Kalisalak, Salaman sebagai mitra utama dalam kegiatan ini.

\section{DAFTAR PUSTAKA}

Hidayat, M.A., Ali Anwar, Noer Hidayah, M. A. H. (2017). Pendidikan Non Formal dalam Edudeena, 11), 31-42. https://doi.org/10.30762/ Meningkatkan Keterampilan Anak Jalanan. 
direm , ini konsekuensinya. https://

ekonomi.bisnis.com/read/20200505/12/

1236810/pengangguran-akibat-covid-19-sulitdirem-ini-konsekuensinya

F, I. J./ ;Tesorier. (2016). Community Development Alternatif Pengembangan Masyarakat di Era Globalisasi.

Giorgi, G., Lecca, L. I., Alessio, F., Finstad, G. L., Bondanini, G., Lulli, L. G., Arcangeli, G., \& Mucci, N. (2020). COVID-19-Related Mental Health Effects in the Workplace: A Narrative Review. International Journal of Environmental Research and Public Health, 1721). https://doi.org/ 10.3390/ijerph17217857

Indonesia, R. (2003). UU RI Nomor 20 Tahun 2003 Sistem Pendidikan Nasional.

Lauer, N. (2002). Community Development Strand Modulel: 1 . 1 Understanding Community Development Lecturer Support Material.

Listyorini. (2020). Memahami Tentang Pembatasan Sosial Berskala Besar (PSBB). https://investor.id/ investory/memahami-tentang-pembatasansosial-berskala-besar-psbb

Notoatmojo. (2014). Ilmu Perilaku Kesehatan. Rineka Cipta.

Organization, W. H. (2020). Coronavirus disease 2019 (COVID-19): situation report, 82. apps.who.int. https://apps.who.int/iris/bitstream/ handle/10665/331780/nCoVsitrep11Apr2020eng.pdf

PHEOC, K. R. (2020). Covid-19. https:// covid19.kemkes.go.id/category/situasi-infeksiemerging/info-corona-virus/\#.X8YFgRYxU2x

Ravaldi, C., \& Vannacci, A. (2020). The COVIDASSESS dataset - COVID19 related anxiety and stress in prEgnancy, poSt-partum and breaStfeeding during lockdown in Italy. Data in Brief, 33, 106440. https://doi.org/10.1016/ j.dib.2020.106440

$\mathrm{RI}, \mathrm{K}$. (2021). Kemenkes raker dengan komite iii dpd ri bahas penanganan pandemi covid-19. 1-2. www.depkes.go.id

Sakri, D. (2020). Menakar Dampak Pandemi COVID19 terhadap Perekonomian Daerah. CSIS Commentaries DMRU-088-ID, 1-10.

Suni, N. S. P. (2020). POTENSI LONJAKAN KASUS COVID-19 PASCA LIBUR PANJANG OKTOBER 2020 DAN UPAYA PENANGGULANGANNYA. 202a November). https://berkas.dpr.go.id/puslit/ files/info_singkat/Info Singkat-XII-21-I-P3DI-
November-2020-1957.pdf

Suryahadi, A., Al Izzati, R., \& Suryadarma, D. (2020). The Impact of COVID-19 Outbreak on Poverty: An Estimation for Indonesia (Draft). SMERU Working Paper, April, 1-20. http://smeru.or.id/en/ content/impact-covid-19-outbreak-povertyestimation-indonesia

Wafiyah. (2015). PEMBERDAYAAN DASA WISMA SEBAGAI UPAYA PEMBERLANGSUNGAN K3 (KEBERSIHAN, KEINDAHAN, DAN KETERTIBAN) DI DUSUN GINTUNGAN, DESA DEYANGAN, KEC. MERTOYUDAN, KAB. MAGELANG. DIMAS, 15.

Z., A. M. B./ ;Antoniputr. A.l ;Annis. D./ ;Fadi. (2020). Analisis Faktor dan Tipologi dalam Kebijakan Pembatasan Sosial Berskala Besar (PSBB) transisi sebagai upaua penanganan covid-19 di DKI Jakarta. https://www.researchgate.net/ publication/345714127_ANALISIS_AKTOR_DAN_TIPOLOGI_DALAM_KEBIJAKAN_PEMBATASAN_SOSIAL_BERSKALA_BESAR_PSBB_TRANSISI_SEBAGAI_UPAYA_PENANGANAN_COVID19_DI_DKI_JAKARTA 